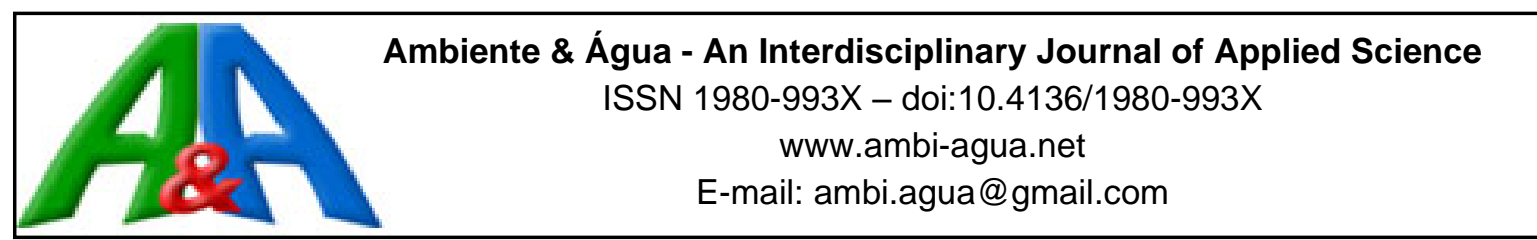

\title{
Soil water-balance-based approach for estimating percolation with lysimeter and in field with and without mulch under micro irrigation
}

\author{
ARTICLES doi:10.4136/ambi-agua.2760
}

Received: 15 Jun. 2021; Accepted: 30 Aug. 2021

\author{
Marcos de Souza Camposi ${ }^{1}$; Eugênio Ferreira Coelho ${ }^{2}$; \\ Marcelo Rocha dos Santos ${ }^{3}$; Rafael Dreux Miranda Fernandes ${ }^{1 *}$; \\ Jailson Lopes Cruz ${ }^{2}$ iD
}

\footnotetext{
${ }^{1}$ Programa Pós-Graduação de Engenharia Agrícola. Universidade Federal do Recôncavo da Bahia (UFRB), Rua Rui Barbosa, n 710, CEP: 44380-000, Cruz das Almas, BA, Brazil. E-mail: marcossc_ufersa@hotmail.com ${ }^{2}$ EMBRAPA Mandioca e Fruticultura Tropical. Empresa Brasileira de Pesquisa Agropecuária (EMBRAPA), Rua Embrapa, s/nº, Caixa Postal 007, CEP: 44380-000, Cruz das Almas, BA, Brazil. E-mail: eugenio.coelho@embrapa.br, jailson.cruz@embrapa.br

${ }^{3}$ Instituto Federal de Educação, Ciência e Tecnologia Baiano (IFBaiano), Zona Rural, Distrito de Ceraíma, CEP: 46430-000, Guanambi, BA, Brazil. E-mail: marcelorochas@yahoo.com.br *Corresponding author. E-mail: rafadreux@gmail.com
}

\begin{abstract}
Precise, accurate knowledge of percolation is key to reliable determination of soil water balance and a crop's water-use efficiency. This work evaluated an approach to estimate the amount of water percolated in the root zone using soil water content (SWC) data measured at different time intervals. The approach was based on the difference of soil water content within and below the effective root zone of banana plants at different time intervals. A drainage lysimeter was used to compare the measured and estimated percolation data. The approach was then used in a banana orchard under drip and micro sprinkler irrigation, with and without the use of mulch. The soil water storage in the banana's root zone was evaluated within a twodimensional soil profile with time domain reflectometry (TDR). Mean percolation measured in the lysimeters did not differ from the approach's estimates using intervals between SWC readings equal to or longer than $6 \mathrm{~h}$ from the end of an irrigation event. Percolation estimates under drip and micro sprinkler irrigation in the field, with and without mulch, were consistent with those measured in the lysimeters, considering the 6-h interval of SWC measurements. Percolation was greater under the drip irrigation system with mulch. The amount of water percolated was not influenced by the presence of mulch under the micro sprinkler system.
\end{abstract}

Keywords: localized irrigation, soil water balance, soil water content sensor.

\section{Abordagem baseada no balanço de água no solo para a estimativa de percolação em lisímetro e em campo com e sem cobertura do solo sob sistemas micro irrigação}

\section{RESUMO}

Conhecimento preciso e exato da percolação é uma chave para a determinação confiável do balanço de água no solo e da eficiência no uso da água pelas culturas. Este trabalho objetivou avaliar uma aproximação para estimar a quantidade de água percolada na zona radicular usando 
dados de umidade do solo (SWC) medidos em diferentes intervalos de tempo. A aproximação se baseou na diferença de umidade do solo dentro e abaixo da camada efetiva do sistema radicular de bananeiras em diferentes intervalos de tempo. Um lisímetro de drenagem foi utilizado para comparar os dados de percolação medida e estimada. A aproximação foi então utilizada em um bananal sob irrigação por gotejamento e por micro aspersão, com e sem cobertura do solo. $\mathrm{O}$ armazenamento de água no solo na zona radicular efetiva da bananeira foi avaliado em um perfil bidimensional do solo com sensores de reflectometria no domínio do tempo (TDR). A percolação média medida em lisímetro não diferiu do valor estimado pela aproximação, utilizando intervalos entre medidas de umidade do solo iguais ou superiores a 6 horas a partir do final do evento de irrigação. Estimativas de percolação sob gotejamento e micro aspersão em campo, com e sem cobertura do solo, foram consistentes com aquelas dos lisímetro, considerando o intervalo de 6 horas entre medições de umidade do solo. A percolação foi maior sob gotejamento com cobertura do solo. A quantidade de água percolada não foi influenciada pela presença da cobertura do solo sob irrigação por micro aspersão.

Palavras-chave: balanço de água no solo, irrigação localizada, sensores de umidade do solo.

\section{INTRODUCTION}

Measuring water loss by percolation is fundamental in determining water application efficiency in irrigated crops, calculating soil water balance, dealing with drainage problems, and preventing contamination of groundwater (Chartzoulakis and Bertaki, 2015; Lai et al., 2016; Ferreira, 2017). Percolation and water uptake by roots are the most difficult components of water balance to measure. Many authors studied percolation under unsaturated root-zone conditions of irrigated crops (Baram et al., 2012; Santana Júnior et al., 2021; Silva and Coelho, 2013; Séré et al., 2012). Determining percolation for soil water balance is crucial for minimizing errors associated with the estimation of crop evapotranspiration (ETc), which plays an important role in irrigation scheduling. Although drip and micro sprinkler irrigations are highly efficient and commonly used in fruit orchards, they have different soil wetting patterns, with possible water losses by percolation, as demonstrated by Nassah et al. (2018).

The amount of water percolated depends on the soil's physical properties and on energy states of soil water. The availability of equipment for estimating the soil water content (SWC) with accuracy (time domain reflectometry and frequency domain reflectometry) allows us to evaluate the processes of soil water dynamics like percolation under irrigated conditions (Ladekarl, 1998; Silva and Coelho, 2013). Silva and Coelho (2013; 2014) and Santana Júnior et al. (2021) used TDR probes to obtain continuous and automated SWC data in order to determine water percolation in drainage lysimeters. One of the limitations for obtaining percolation with the use of continuous and automated SWC data is the high cost of this equipment.

Alternatives for estimating SWC include the use of low-cost capacitance sensors (Pizetta et al., 2017), electrical resistance sensors (Salman et al., 2021; Shock et al., 2013), and tensiometers. Percolation with regard to flow rate and its calculation between irrigation events requires the knowledge of a representative time interval between SWC readings.

Lysimeters are useful tools to study and quantify the water and chemical fluxes in soil (Pütz et al., 2018), allowing the performance of experiments under controlled soil conditions under natural meteorological conditions. Lysimeters have been widely used to quantify evaporation and evapotranspiration (Graham et al., 2018; López-Urrea et al., 2020; Pütz et al., 2018), and to calibrate and test numerical models of water flow and chemical transport (Kupfersberger et al., 2017; Tu et al., 2021; Wang et al., 2018). Duncan et al. (2016) used drainage lysimeters to study groundwater recharge from rainfall and irrigation in pasture areas

Rev. Ambient. Água vol. 16 n. 5, e2760 - Taubaté 2021 
of New Zealand, using three sets of three drainage lysimeters in irrigated dairy farms.

Following an irrigation event, soil water is mainly influenced by gravitational and matric gradients associated with diffusivity and unsaturated hydraulic conductivity, where infiltration and water redistribution in the soil occur simultaneously. After that, percolation occurs, losing intensity with time.

Percolation has been estimated mainly by numerical mathematical models which need soil properties as inputs for computer programs (Panigrahi and Panda, 2003); these properties include diffusivity and unsaturated soil hydraulic conductivity. This work proposes an approach for determination of the percolated water depth between two irrigation events in a twodimensional soil profile near the plant. This approach is based only on SWC readings in a whole profile both in the effective rooting zone and below it.

The present work: $(i)$ evaluated an approach for estimating percolation beneath the rooting zone of banana trees in lysimeter; and, (ii) determined the soil water balance components in banana trees effective root zone, grown with and without soil covering, under micro irrigation at field conditions, by applying the approach evaluated in a lysimeter (objective $i$ ).

\section{MATERIAL AND METHODS}

Experiments were carried out at Embrapa, Mandioca and Fruticultura, in Cruz das Almas, Bahia State, Brazil (1248' S; 3906' W; 225 altitude), between November 2015 and February 2016. The experiments were conducted: (i) using banana plants, grown in drainage lysimeters and (ii) in a banana orchard grown under field conditions. The climate of the region is humid to sub-humid with annual average precipitation of $1143 \mathrm{~mm}$. The soil of the lysimeters had a sandy-clay texture (493.5 $\mathrm{g} \mathrm{kg}^{-1}$ of sand; 89 of silt; $417.5 \mathrm{~g} \mathrm{~kg}^{-1}$ of clay) and bulk density of $1.40 \mathrm{~g} \mathrm{~cm}^{-3}$. The soil in the field experiment had a sandy clay loam texture $\left(571 \mathrm{~g} \mathrm{~kg}^{-1}\right.$ of sand, $103 \mathrm{~g} \mathrm{~kg}^{-1}$ of silt; and $324 \mathrm{~g} \mathrm{~kg}^{-1}$ of clay) and bulk density of $1.50 \mathrm{~g} \mathrm{~cm}^{-3}$.

\subsection{Lysimeter experiment characterization}

A lysimeter with an area of $5.0 \mathrm{~m}^{3}(2.0 \mathrm{~m}$ wide, $2.5 \mathrm{~m}$ long and $1.0 \mathrm{~m}$ deep $)$ was installed at the center of a 0.5 ha banana orchard. A drainage system at the bottom of the lysimeter allowed water to drain freely, using perforated PVC pipes of $0.032 \mathrm{~m}$ of diameter, covered with a $0.1 \mathrm{~m}$-deep layer of washed sand. Time domain reflectometry (TDR) probes were installed at the depths of $0.8,0.6,0.4$ and $0.2 \mathrm{~m}$, and at the distances of $0.2,0.4,0.6$ and $0.8 \mathrm{~m}$ from the center of the lysimeter, forming a two-dimensional grid with 16 points (probes) for soil moisture readings.

The TDR probes consisted of three 0.10-m-long stainless-steel rods connected to $3.5-\mathrm{m}$ long coaxial cables attached to multiplexers. The multiplexers were connected to a station composed of a TDR reflectometer and a data logger recording and storing data.

Soil water content (SWC) data were measured and stored every 20 minutes. The TDR probes were calibrated, according to the methodology described by Silva and Coelho (2013), obtaining Equation 1.

$$
\theta=6 E-5 K a^{3}-0.0032 K a^{2}+0.0631 K a-0.2422 ; \mathrm{R}^{2}=0.98
$$
$\left.\mathrm{cm}^{-3}\right)$.

Where, $\mathrm{Ka}$ is the bulk dielectric constant and $\theta$ is the volumetric soil water content $\left(\mathrm{cm}^{3}\right.$

Six micro sprinklers with $56 \mathrm{~L} \mathrm{~h}^{-1}$ flow rate irrigated the banana plant in the lysimeter, three emitters on each side and at $0.40 \mathrm{~m}$ from the plant. Water application uniformity resulted in an average Christiansen coefficient of $89 \%$ (Conceição, 2016). Irrigation was performed daily. The lysimeter experiment followed a completely randomized design, in split-plots with 
three replicates. The plots consisted of the methodologies used to measure percolation (SWC readings from TDR probes, and lysimeter percolation volume), and the subplots consisted of six intervals between SWC measurements $(2,4,6,8,10$ and $12 \mathrm{~h})$.

\subsection{Field experiment characterization}

The field experiment was carried out from November to February 2016 with "BRS Princesa" banana spaced at $2.5 \times 2.5 \mathrm{~m}$. Three $4 \mathrm{~L} \mathrm{~h}^{-1}$ drippers spaced $0.5 \mathrm{~m}$ apart on a lateral line per row irrigated each plant located in the middle of the three emitters. A micro sprinkler system was also used, with one lateral line per two rows of plants and micro sprinklers having $64 \mathrm{~L} \mathrm{~h}^{-1}$ flow rate located in the middle of four plants. The same amount of water was applied to plots and subplots. Irrigation scheduling was based on crop evapotranspiration (ETc), which is the product of reference evapotranspiration (ETo) and crop coefficient (Kc). Reference evapotranspiration was obtained using the Penman-Monteith-FAO method (Allen et al., 2006). To do so, meteorological data measured by an automatic weather station located near to the experiment were used. The correction coefficient for localized irrigation systems was set at 1 (Coelho et al., 2015). The irrigation frequency was 24 hours (1 day).

The experiment followed a completely randomized design in split-split plots with four repetitions. Plots consisted of two irrigation systems (drip and micro sprinkler), subplots consisted of two soil coverage conditions (bare soil and mulch), and sub-subplots consisted of six intervals $(2,4,6,8,10$ and $12 \mathrm{~h})$ from the end of the irrigation event to the next event.

Around 60 days before collecting data, TDR probes were installed within the plant's root zone in each sub-subplot. The probes were distributed at distances of $0.25,0.5,0.75$ and 1.00 $\mathrm{m}$ from the plant and at depths of $0.2,0.4,0.6$ and $0.8 \mathrm{~m}$, forming a two-dimensional SWC monitoring grid consisting of 16 probes in each plot and subplot. The TDR probes and the recording/storing system were identical to those used in the lysimeter experiment. The calibration of the TDR probes resulted in Equation 2.

$\theta=5.65 E-5 K a^{3}-0.003516 K a^{2}+0.08044 K a-0.43272$

Where, $\theta$ is the soil volumetric water content $\left(\mathrm{cm}^{3} \mathrm{~cm}^{-3}\right)$ and $\mathrm{Ka}$ is the apparent dielectric constant of the soil; $\mathrm{R}^{2}=0,99$.

\subsection{Percolation estimates in lysimeters and in the field}

We selected 5-d-long periods with daily ETo values showing little variation $( \pm 0.64 \mathrm{~mm})$ for the assessment of percolation. Crop evapotranspiration was the product of ETo, Kc and a coefficient for localized irrigation (Keller and Bliesner, 1990), the latter being assumed as constant during the 5 -d period. The evaluation considered five irrigation cycles $(24 \mathrm{~h})$, each one as a replicate. Percolation was estimated, both in the field and lysimeters, based on the evaluation of water storage in the soil layer between 0.60 and $0.80 \mathrm{~m}$ deep $(\mathrm{z})$ and at a distance (r) from the plant of 0.0 to $1.0 \mathrm{~m}$ (Equation 3). Measurements of soil water storage were performed at the two-dimensional profiles during five time intervals after the irrigation event.

$$
\mathrm{S}_{\mathrm{ti}}=\int_{0}^{0.80} \int_{0}^{1.0}\left(\theta_{\mathrm{ti}}\right)_{\mathrm{r}, \mathrm{z}} \mathrm{dzdr}-\int_{0}^{0.60} \int_{0}^{1.0}\left(\theta_{\mathrm{ti}}\right)_{\mathrm{r}, \mathrm{z}} \mathrm{dzdr}
$$

Where, $\left(\theta_{\mathrm{ti}}\right)_{\mathrm{r}, \mathrm{z}}$ is the soil water content at a distance $\mathrm{r}$ from the plant and at a depth $\mathrm{z}$ from the soil surface, and $\mathrm{S}_{\mathrm{ti}}$ is the amount of water stored within the soil layer between 0.60 and $0.80 \mathrm{~m}$ deep and at the time $t_{i}$, which can assume the values $t_{i}$ and $t_{i+1}$. Soil water contents were measured every 2, 4, 6, 8 and $12 \mathrm{~h}$ after an irrigation event. Automatic measurements by the TDR lasted for $24 \mathrm{~h}$. This period corresponded to an irrigation cycle. The amount of water percolated (PER) within the interval of time $t_{i}-t_{i+1}$ is given by the difference of storage within 
the layer between 0.60 and $0.80 \mathrm{~m}$ in the intervals (Equation 4).

$$
P E R_{t i-t i+1}=\frac{s_{t_{i+1}}-s_{t_{i}}}{t_{i+1-t_{i}}}
$$

Where, $P E R_{t i-t i+1}$ is the amount of water $(\mathrm{mm})$ percolated from the effective root zone estimated at the layer $0.60-0.80 \mathrm{~m}$ within an interval of time $\mathrm{t}_{\mathrm{i}+1}-\mathrm{t}_{\mathrm{i}} ; \mathrm{S}$ is the water storage $(\mathrm{mm})$ in this layer at time $t_{i}$ or $t_{i+1}$. Total percolation between two irrigation events $(24 \mathrm{~h})$ was determined by adding up all percolation measurements for each interval (Equation 5).

$$
\mathrm{PER}_{24 \mathrm{hs}}=\sum_{\mathrm{i}=1}^{23} \mathrm{PER}_{\mathrm{ti}-\mathrm{ti}+1}
$$

Where $\mathrm{n}$ refers to the number of intervals $(\Delta \mathrm{t})$ in $24 \mathrm{~h}$, i.e., $\Delta \mathrm{t}=2 \mathrm{~h}, \mathrm{n}=12 ; \Delta \mathrm{t}=4 \mathrm{~s}, \mathrm{n}=$ 6; $\Delta \mathrm{t}=6 \mathrm{~h}, \mathrm{n}=4 ; \Delta \mathrm{t}=6 \mathrm{~h}, \mathrm{n}=4$ and $\Delta \mathrm{t}=12 \mathrm{~h}, \mathrm{n}=2$. We assumed that percolation was negligible during an irrigation event because soil water contents were lowest within the root zone right before the onset of irrigation and started to increase below the effective rooting depth only near the end of irrigation.

The choice of the best time interval to calculate the percolation after an irrigation event in the field was based on the comparison of the amount of percolated water measured in the lysimeters with the values estimated by the Equations 3 and 4. Measured and estimated percolated water data were tested by analysis of variance and Snedeccor's F test. Then, means were compared using the Tukey test. Evaluating the proposed approach in the lysimeter permitted us to estimate the percolation occurring within a soil profile under drip- and micro sprinkler irrigation systems, with and without mulching composed of banana litter.

\section{RESULTS AND DISCUSSION}

\subsection{Lysimeter percolation estimate}

Mean amounts of percolated water estimated by the approach based on readings of soil water content at intervals of six, eight, 10 or 12 hours between irrigation events were not significantly different from those measured in the lysimeter drains (Table 1).

Table 1. Means of percolated water $(\mathrm{mm})$ estimated by the proposed approach based on TDR readings of soil water content (SWC) and the amount of water measured in drainage lysimeters for different intervals of SWC measurements within the two-dimensional profiles for a 24-h irrigation cycle.

\begin{tabular}{ccccccc}
\hline \multirow{2}{*}{ Method } & \multicolumn{6}{c}{ Interval between soil water content measurements (hours) } \\
\cline { 2 - 7 } & 2 & 4 & 6 & 8 & 10 & 12 \\
\hline Approach & $3.39 \mathrm{a}$ & $0.70 \mathrm{a}$ & $0.25 \mathrm{~b}$ & $0.29 \mathrm{~b}$ & $0.17 \mathrm{~b}$ & $0.12 \mathrm{~b}$ \\
Lysimeter & $0.22 \mathrm{~b}$ & $0.22 \mathrm{~b}$ & $0.22 \mathrm{~b}$ & $0.22 \mathrm{~b}$ & $0.22 \mathrm{~b}$ & $0.22 \mathrm{~b}$ \\
\hline
\end{tabular}

CV $35.38 \%$

Means followed by the same letter in the column are not different, based on Tukey's test at $5 \%$ of probability.

These results revealed that carrying out SWC readings at short intervals is not necessary. Longer intervals make percolation assessment more practical and less time-consuming. A potential model was fitted to the data on the amount of percolated water as a function of reading interval (Figure 1). The model had a root square mean error of $0.6 \mathrm{~mm}$. The larger deviations 
between estimated and measured percolation took place two to four hours after irrigation. Soil water content (SWC) measured every $2 \mathrm{~h}$ after the irrigation resulted in deviations of up to 3.0 $\mathrm{mm}$ from values estimated by the approach (Equations 3 and 4). The highest drop in water percolation occurred after $4 \mathrm{~h}$ from the end of irrigation according to the increase in intervals between SWC measurements after irrigation. At 6-h intervals between measurements, the rate at which the amount of percolated water decreases as time passes tended to zero (Figure 1).

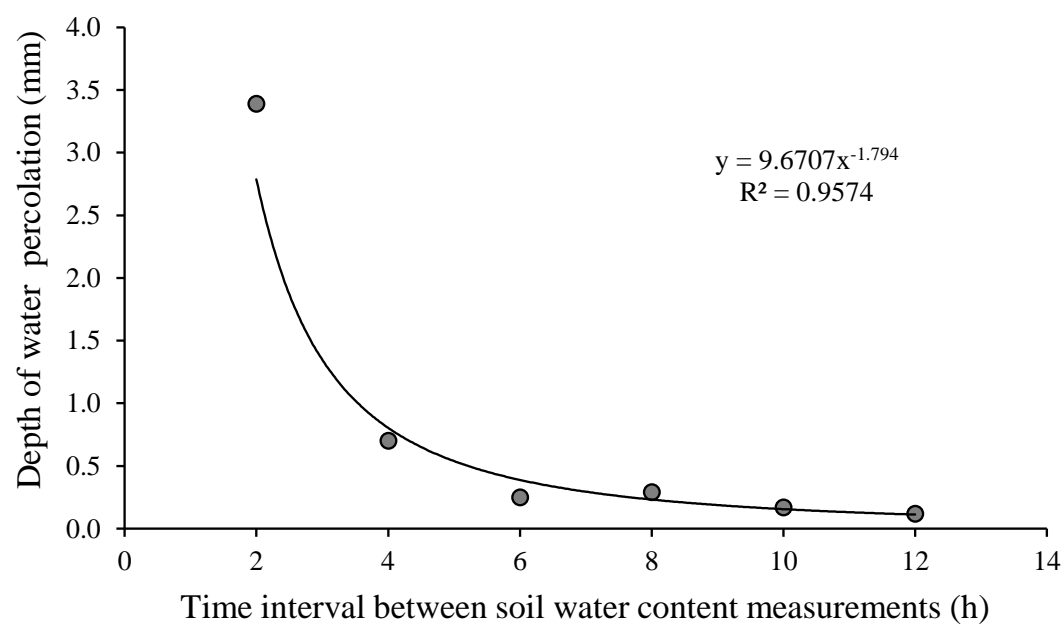

Figure 1. Percolated water amount as a function of time interval between SWC readings within the soil profile in drainage lysimeters.

Shorter time intervals ( 2 and $4 \mathrm{~h}$ ) overestimated percolation when compared to longer time intervals (10 and $12 \mathrm{~h}$ ). The results indicate that the estimation of the amount of percolated water over a 24 -h period needs 6- to 10-h intervals between SWC readings within the twodimensional soil profiles close to the plant because no significant difference was observed when comparing the two reading intervals.

The more adequate intervals of SWC readings within the soil profile in the lysimeters for measuring percolation were different from the ones reported by Silva and Coelho (2014), who integrated the obtained data by TDR to the Darcy-Buckingham Equation. The adequate interval verified in our study was within the recommendation of those authors who considered adopting time intervals for SWC readings above $1 \mathrm{~h}$ in drainage lysimeters, without plants. In the case of estimating percolation by using soil water content data by our approach (Equations 3 and 4), prior knowledge of hydraulic properties of the soil is not necessary; however, knowing the soil's physical attributes, such as texture, soil bulk density and soil-water retention curve is needed for extrapolation of recommendations.

Figure 1 shows a decreasing percolation rate as time passes up to $6 \mathrm{~h}$ from the end of irrigation, though the volume of percolated water is largest during this 6-h period because within the first hours after irrigation, all the applied water is being redistributed due to matric or gravitational potential gradients and root uptake (Hillel, 2013). Gravity drives the flow of water below the root zone - percolation -, which relates to the water not retained in soil pores after an irrigation event. Within the effective root depth, gravitational gradients tend to decrease as time passes. The amount of water in the more superficial macropores decreases and water flow becomes more dependent on the non-saturated soil hydraulic conductivity (Satchithanantham et al., 2014). These authors observed in their TDR readings a decrease in SWC in the root zone of potato as time passes, with minimum variations in the deeper layers. Root-water extraction also contributes to decreasing water percolation, mainly during the first hours after an irrigation event, because of the larger gradient of water potential between soil and root. 


\subsection{Field percolation prediction}

The approach's performance based on evaluation of SWC data from lysimeters proved to be feasible for use under field conditions, as long as the time elapsed from the end of irrigation is more than $6 \mathrm{~h}$. The analysis of variance for the field experiment detected a significant effect of the interaction between the micro irrigation systems and mulch in percolation data. The higher means of water percolation were observed in drip-irrigated bananas (Table 2). There was no statistical difference in percolation between bare and mulched soil for both irrigation systems. However, the total percolated water under the drip irrigation with mulch was $26.4 \%$ greater than the total percolation under drip irrigation with bare soil.

Table 2. Means of total water percolation $\left(\mathrm{mm} \mathrm{d}^{-1}\right)$ in the drip and micro sprinkler irrigation systems on soil with and without mulch composed of banana biomass under field condition.

\begin{tabular}{ccc}
\hline \multirow{2}{*}{ Treatments } & \multicolumn{2}{c}{ Mulch } \\
\cline { 2 - 3 } & With & Without \\
\hline Drip irrigation & $0.67 \mathrm{aA}$ & $0.53 \mathrm{aB}$ \\
Micro sprinkler irrigation & $0.29 \mathrm{bB}$ & $0.28 \mathrm{bB}$ \\
\hline CV\% & \multicolumn{2}{c}{18,16} \\
\hline
\end{tabular}

Means followed by the same lowercase letter in the columns and uppercase letters in the rows are not significantly different based on Tukey's test at 5\% probability.

Potential models fitted to percolated water data as a function of the time interval between SWC readings represented the interaction between the time interval between SWC measurements and the irrigation system (Figure 2). The models had a root square mean error of $0.28 \mathrm{~mm}$ for the drip system and of 0.18 for the micro sprinkler system. Both potential models showed a goodness of fit of 0.999 for drip and micro sprinkler irrigation systems (Figure 2).

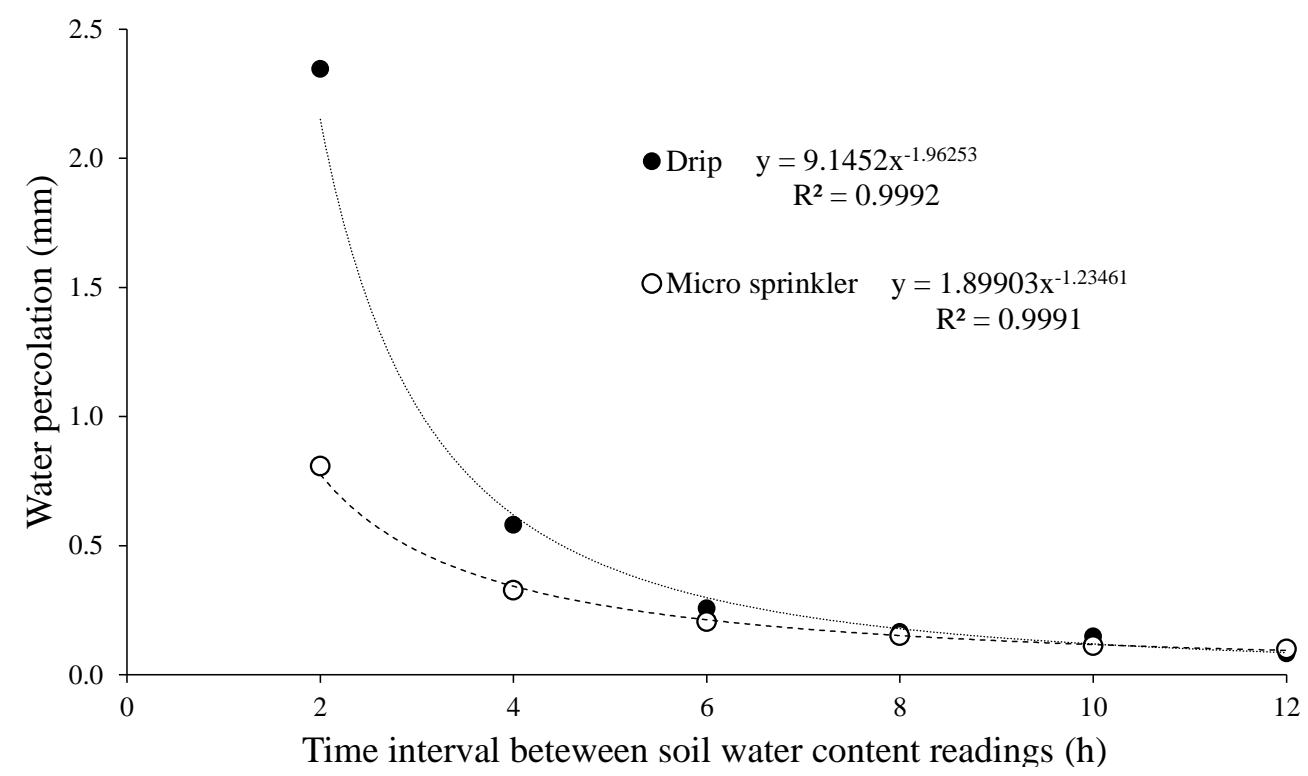

Figure 2. Percolated water amount as a function of the interval between SWC readings for drip and micro sprinkler systems in field-grown bananas.

The longer the intervals between SWC measurements, the lower mean percolation for both irrigation systems (Figure 2). Percolation was more expressive for the intervals of SWC readings of 2 and $4 \mathrm{~h}$ for drip- and micro sprinkler irrigation systems. Mean percolation 
measurements every 2 and $4 \mathrm{~h}$ were overestimated when compared to those measured at intervals longer or equal to $6 \mathrm{~h}$.

Field results are consistent with those obtained from lysimeters when using the proposed approach (Equation 3, 4 and 5). Therefore, for both soils, the approach may be used at field conditions, regardless of differences in texture and structure.

The feasibility of the approach for measuring percolation in 1-m-deep lysimeters indicates the possibility of using it under field conditions. The field results showed that water percolation in the mulched soil cultivated with banana was higher under drip irrigation than under micro sprinkler irrigation. This is due to the wetted volume of soil beneath a dripper being smaller than that beneath a micro sprinkler. Moreover, a micro sprinkler wets a larger area than a dripper does, resulting in a greater evaporative area on the soil surface; therefore, the lower application intensity and water storage in the soil leads to lower percolation. The same volume of water is redistributed within a smaller soil volume under drip irrigation, and, therefore, the smaller volume of soil should contain more water than within the larger wetted volume beneath a micro sprinkler. The larger amount of water, redistributed in macropores, is more strongly affected by gravity, thereby increasing percolation.

Furthermore, mulch makes evaporation negligible, thus increasing water volume stored in the smaller volume of soil wetted by drippers as compared with the volume of soil wetted by micro sprinklers. This greater water volume stored in the wetted soil volume enhances the total potential gradients, responsible for the greater flow/percolation in comparison with the micro sprinkler system. Our results are in agreement with those obtained by Mota et al. (2010), who reported increased stored water in the soil due to mulching at the early and vegetative stages of mulched melon plants under drip irrigation. Anjos et al. (2017), working in a Plinthosols under levels of mulches composed of sugarcane biomass, observed that keeping $50 \%$ of the soil covered promoted a better conservation of soil moisture, taking 11 days for the soil to reach the critical water storage.

Under drip irrigation, the percolation measured in the covered soil did not differ statistically from that measured in uncovered soil. Water losses under drip irrigation are associated with soil evaporation, plant transpiration and percolation. Evaporation under drip irrigation is more relevant for smaller ground cover, or at the early plant growth stages (Bonachela et al., 2001). The banana crop was, at flowering phase during data sampling, covering the whole ground. This fact contributed to the reduction of soil evaporation on bare soil, so the difference in percolation recorded between mulched soil and bare soil was minimal, regardless of the irrigation system. Yet, the small difference in percolation for drip irrigation systems is due to water losses through plant transpiration and percolation in the covered soil, which increases the amount of water stored within the wetted volume between irrigation events, contributing to the increase on the water potential gradients. These results corroborate those of Lu et al. (2020) and Pereira et al. (2015), who reported that corn-based mulch decreases soil temperature and evaporation and increases soil water content. Jun et al. (2014) reported increases in soil water storage and forage yields on biomass-covered soils. Nassah et al. (2018) estimated percolation in drip-irrigated citrus orchards, with irrigation amounts calculated based on the FAO-56 equation, and verified that, on average, $38.3 \%$ of the applied water had percolated.

The models fitted to percolation as function of time intervals between SWC readings (Figure 2) indicated, as in Figure 1, adequate intervals of $6 \mathrm{~h}$ or more for obtaining percolation within the soil profiles under both micro-irrigation systems. Reading the SWC every 2 or $4 \mathrm{~h}$ within a 24-h period increases the chances of variations in SWC readings, which is more intense during the initial period after an irrigation. Soil water content varies within the soil profile, regardless of the time elapsed from the end of an irrigation event, due to soil water infiltration and redistribution. Larger intervals between readings remove these variations and present more 
coherent SWC values at the two-dimensional profile. Additionally, right after the end of the irrigation event, SWC measurements in the more superficial layer present higher values, which excessively increases water storage in the soil profile and the percolated volume.

Additionally, the results indicate that the proposed approach can be employed for other rooting depths as long as the grid of points for SWC measurements includes the soil layer immediately below the effective root depth. The great advantage of the approach lies in the fact that it requires only SWC data. The approach may be used on electronic spreadsheets and does not require the use of complex analytical or numerical models.

\section{CONCLUSIONS}

An approach was proposed to estimate the amount of percolated water below the effective root depth (deep percolation). Predictions were highly consistent with the percolated amount obtained in a drainage lysimeter for 6-h intervals or longer between soil water content (SWC) readings in the soil profile.

The percolated amounts estimated by the approach in a field-grown banana orchard under drip and micro sprinkler irrigation with and without mulch (banana biomass) were consistent with the estimated percolation under lysimeter conditions, provided that the interval between SWC measurements in the soil profile is equal to or greater than six hours.

Percolation within the soil profile under the drip irrigation system is higher than that under the micro sprinkler system, considering the same volume of water applied to the crop.

The proposed approach for predicting soil water percolation below the effective root zone is feasible and easy-to-use under field conditions for the purpose of estimating soil water balance within the root zone.

\section{ACKNOWLEDGEMENTS}

We thank CNPq and EMBRAPA for funding this research through the following projects: CNPq 403986/2016-8 e SEG EMBRAPA 13.16.05.018.00.00.

\section{REFERENCES}

ALLEN, R. G.; PEREIRA, L. S.; RAES, D.; SMITH, M. Evapotranspiración del cultivo: Guias para la determinación de los requerimientos de agua de los cultivos. Roma: FAO, 2006. 298p.

ANJOS, J. C. R.; ANDRADE JÚNIOR, A. S.; BASTOS, E. A.; MELO, F. B.; BRITO, R.R. Armazenamento de água em Plintossolo Argilúvico cultivado com cana-de-açúcar sob níveis de palhada. Pesquisa Agropecuária Brasileira, v. 52, p. 464-473, 2017. https://doi.org/10.1590/S0100-204X2017000600010

BARAM, S.; KURTZMAN, D.; DAHAN, O. Water percolation through a clayey vadose zone. $\begin{array}{llllll}\text { Journal of Hydrology, v. 424, p. } 2012 . & \text { 165-171, }\end{array}$ https://doi.org/10.1016/j.jhydrol.2011.12.040

BONACHELA, S. et al. Soil evaporation from drip-irrigated olive orchards. Irrigation Science, v. 20, n. 2, p. 65-71, 2001. https://doi.org/10.1007/s002710000030

CHARTZOULAKIS, K.; BERTAKI, M. Sustainable water management in agriculture under climate change. Agriculture and Agricultural Science Procedia, v. 4, p. 88-98, 2015. https://doi.org/10.1016/j.aaspro.2015.03.011 
COELHO, E. F.; SILVA, A. J. P.; DONATO, S. L. R.; SANTANA JUNIOR, E. B.; OLIVEIRA, P. M. Sistemas de irrigação localizada e manejo de água em bananeira. Informe Agropecuário, v. 36, n. 288, 2015.

CONCEIÇÃO, B. S. Modelagem da dinâmica de nitrato e potássio no solo em bananeiras fertirrigadas: Modelos paramétricos e modelo hydrus. 2016. 105f. Tese (Doutorado em Engenharia Agrícola) - Universidade Federal de Viçosa, Viçosa, 2016.

DUNCAN, M. J.; SRINIVASAN, M. S.; MCMILLAN, H. Field measurement of groundwater recharge under irrigation inCanterbury, New Zealand, using drainage lysimeters. Agricultural Water Management, v. 166, p. 17-32, 2016. http://dx.doi.org/10.1016/j.agwat.2015.12.002

FERREIRA, M. I. Stress coefficients for soil water balance combined with water stress indicators for irrigation scheduling of woody crops. Horticulturae, v. 3, n. 2, p. 38, 2017. https://doi.org/10.3390/horticulturae3020038

GRAHAM, S. L.; SRINIVASAN, M.S.; FAULKNER, N.; CARRICK, S. Soil hydraulic modeling outcomes with four parameterization methods: Comparing soil description and inverse estimation approaches. Vadose Zone Journal, v. 17, n. 1, p. 170002, 2018. https://doi.org/10.2136/vzj2017.01.0002

HILLEL, D. Introduction to soil physics. Cambridge: Academic press, 2013.

JUN, F.; YU, G.; QUANJIU, W.; MALHI, S. S.; YANGYANG, L. Mulching effects on water storage in soil and its depletion by alfalfa in the Loess Plateau of northwestern China. $\begin{array}{llllll}\text { Agricultural Water Management, } & \text { v. 138, p. 10-16, } 2014 .\end{array}$ https://doi.org/10.1016/j.agwat.2014.02.018

KELLER, J.; BLIESNER, R. D. Sprinkle and trickle irrigation. New York: Avibook, 1990.

KUPFERSBERGER, H.; KLAMMLER, G.; SCHUHMANN, A.; BRÜCKNER, L.; KAH, M. Modeling subsurface fate of s-metolachlor and metolachlor ethane sulfonic acid in the Westliches Leibnitzer Feld aquifer. Vadose Zone Journal, v. 17, n. 1, p. 170030, 2017. http://doi.org/10.2136/vzj2017.01.0030

LADEKARL, U. L. Estimation of the components of soil water balance in a Danish oak stand from measurements of soil moisture using TDR. Forest Ecology and Management, v. 104, n. 1-3, p. 227-238, 1998. https://doi.org/10.1016/S0378-1127(97)00266-1

LAI, X.; LIAO, K.; FENG, H.; ZHU, Q. Responses of soil water percolation to dynamic interactions among rainfall, antecedent moisture and season in a forest site. Journal of Hydrology, v. 540, p. 565-573, 2016. https://doi.org/10.1016/j.jhydrol.2016.06.038

LÓPEZ-URREA, R.; SÁNCHEZ, J. M.; DE LA CRUZ, F.; GONZÁLEZ-PIQUERAS, J.; CHÁVEZ, J. L. Evapotranspiration and crop coefficients from lysimeter measurements for sprinkler-irrigated canola. Agricultural Water Management, v. 239, p. 106260, 2020. https://doi.org/10.1016/j.agwat.2020.106260

LU, H.; XIA, Z.; FU, Y.; WANG, Q.; XUE, J.; CHU, J. Response of Soil Temperature, Moisture, and Spring Maize (Zea mays L.) Root/Shoot Growth to Different Mulching Materials in Semi-Arid Areas of Northwest China. Agronomy, v. 10, n. 4, p. 453, 2020. http://dx.doi.org/10.3390/agronomy 10040453 
MOTA, J. C. A.; LIBARDI, P. L.; BRITO, A. S.; ASSIS JÚNIOR, R. N.; AMARO FILHO, J. Armazenagem de água e produtividade de meloeiro irrigado por gotejamento, com a superfície do solo coberta e desnuda. Revista Brasileira de Ciência do Solo, v. 34, n. 5 , p. 1721-1731, 2010. https://doi.org/10.1590/S0100-06832010000500024

NASSAH, H.; ER-RAKI, S.; KHABBA, S.; FAKIR, Y.; RAIBI, F.; MERLIN, O.; MOUGENOUT, B. Evaluation and analysis of deep percolation losses of drip irrigated citrus crops under non-saline and saline conditions in a semi-arid area. Biosystems $\begin{array}{lllll}\text { Engineering, } & \text { v. } & 165, & \text { p. } & 10-24,\end{array}$ https://doi.org/10.1016/j.biosystemseng.2017.10.017

PANIGRAHI, B.; PANDA, S. N. Field test of a soil water balance simulation model. Agricultural Water Management, v. 58, n. 3, p. 223-240, 2003. https://doi.org/10.1016/S0378-3774(02)00082-3

PEREIRA, F. F. S.; MATSURA, E. E.; MOUSINHO, F. E. P.; BIZARI, E. D. R. Retenção de água em níveis de cobertura morta no feijoeiro irrigado em sistema plantio direto. Irriga, v. 20, n. 3, p. 557-569, 2015. https://doi.org/10.15809/irriga.2015v20n3p557

PIZETTA, S. C.; RODRIGUES, R. R.; PEREIRA, G. M.; PACHECO, F. E. D.; VIOLA, M. R. V.; LIMA, L. A. Calibração de um sensor capacitivo para estimativa da umidade em três $\begin{array}{llllllll}\text { classes de solos. Irriga, v. 22, } & \text { n. 3, p. 458-468, } 2017 .\end{array}$ https://doi.org/10.15809/irriga.2017v22n3p458-468

PÜTZ, T.; FANK, J.; FLURY, M. Lysimeters for vadose zone research. Vadose Zone Journal, v. 17, p. 180035, 2018. http://doi.org/10.2136/vzj2018.02.0035

SALMAN, A. K.; ALDULAIMY, S. E.; MOHAMMED, H. J.; ABED, Y. M. Performance of soil moisture sensors in gypsiferous and salt-affected soils. Biosystems Engineering, 209, p. 200-209, 2021. https://doi.org/10.1016/j.biosystemseng.2021.07.006

SANTANA JUNIOR, E. B.; COELHO, E. F.; SANTOS, M. R.; SILVA, A. J. P.; REIS, J. R. S.; PEREIRA, B. L. S. Management of trickle irrigation for banana: Hydrodynamic processes and sensor placement at root zone. Revista Brasileira de Engenharia Agrícola e Ambiental, v. 25, n. 5, p.312-318, 2021. http://dx.doi.org/10.1590/18071929/agriambi.v25n5p312-318

SATCHITHANANTHAM, S.; KRAHN, V.; SRI RANJAN, R.; SAGER, S. Shallow groundwater uptake and irrigation water redistribution within the potato root zone. Agricultural Water Management, v. 132, p. 101-110, 2014. https://doi.org/10.1016/j.agwat.2013.10.011

SHOCK, C. C.; WANG, F. X.; FLOCK, R. J.; FELIBERT, E. B. G.; SHOCK, C. A.; PEREIRA, A. B.; JENSEN, L. B. Irrigation monitoring using soil water tension. Corvallis: Oregon State University Extension Service, 2013.

SILVA, A. J. P.; COELHO, E. F. Water percolation estimated with time domain reflectometry (TDR) in drainage lysimeters. Revista Brasileira de Ciência do Solo, v. 37, n. 4, p. 920 927, 2013. https://doi.org/10.1590/S0100-06832013000400009

SILVA, A. J. P.; COELHO, E. F. Estimation of water percolation by different methods using TDR. Revista Brasileira de Ciência do Solo, v. 38, n. 1, p. 73-81, 2014. https://doi.org/10.1590/S0100-06832014000100007 
SÉRÉ, G.; OUVRARD, S.; MAGNENET, V.; PEY, B.; MOREL, J. L.; SCHWARTZ, C. Predictability of the evolution of the soil structure using water flow modeling for a constructed technosol. Vadose Zone Journal, v. 11, n. 1, 2012. https://doi.org/10.2136/vzj2011.0069

TU, L. H.; BOULANGE, J.; PHONG, T. K.; THUYET, D. Q.; WATANABE, H.; TAKAGI, $\mathrm{K}$. Predicting rice pesticide fate and transport following foliage application by an updated PCPF-1 model. Journal of Environmental Management, 277, 111356, 2021. https://doi.org/10.1016/j.jenvman.2020.111356

WANG, J.; BOGENA, H. R.; VEREECKEN, H.; BRÜGGEMANN, N. Characterizing redox potential effects on greenhouse gas emissions induced by water-level changes. Vadose Zone Journal, v. 17, 170152, 2018. http://doi.org/10.2136/vzj2017.08.0152 